\title{
溶接部ならびに鋳物の透過 $\mathrm{X}$ 線写真にあらわれる影 (第 1 報)*
}

一影の形態とその特長一

渡辺統市**

\author{
The mottling Appeared on Radiograph of Weldments \\ and Castings (1st Report.)* \\ -Appearances and Characters of the Mottling-
}

by Toichi Watanabe**

\begin{abstract}
The mottled appearance frequently observed in radiograph of austenitic stainless steel weldments and castings has been investigated. The results may be summarized as follows.

1. It has been established that the $\mathrm{X}$-ray diffraction causes the mottling. Diffraction theory (Bragg's law), however, does not explain the whole phenmena. 2. The relation between the incident beam angle and the mottling was obtained. 3. It was observed that the mottling was more pronounced on radiograph taken with a low voltage than on one taken with high voltage. 4. Solution treatment does not affect the mottling. 5. The mottling disappeared when the specimen was recrystallized.
\end{abstract}

\section{I. 緒言}

オーステナイト系ステンレス鋼溶接部の透過 $\mathrm{X}$ 線写真 にあらわれるまだら模様は影と呼ばれ，数年前から多数 の関心を集めてきた. 特に日本溶接協会化学機械溶接委 員会ならびに日本非破羁検查劦会ではこの問題に関する 討論がしばしば行なわれ，多くの研究成果が発表されて

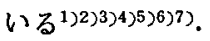

いっぽう溶接金属と類似した凝固組織を示す鈜物につ いてあ，その透過X線写真には影のあらわれることが古 くから知られており，そてです影の発生原因をめぐって



現在までに提出されている影の発生機構としては次の あのがある．その 1 つは粗大結晶粒によるX線の回折に よって影があらわれるというものである.との説は影の 特長すなわち影は柱状晶をかたちどってあらわれるとい うことならびに影はしばしば黒と白の模様が対になって あらわれるという現象を説明しやすいととから多くの研

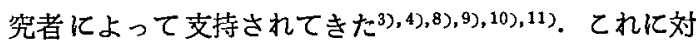
し影は成分元素の偏析によって生ずるという考え方があ る. 柱状晶内でミクロ的偏析があれば，各元素によって X線の吸収率が異なるので，フイルム上で濃淡つまり影 となってあらわれるというあのである゙2. 以上に述べた 2 つの機構はいずれる徤全な結晶粒から影が発生してい

\footnotetext{
*原槁受付 昭和 47 年 1 月14日（16年度秋季晪演会にて発表）

**正貝 名古屋工業大学 Member, Nagoya Institute of Technology
}

るとするすのであるが，これに対し凝固組織の粒界につ いてあ影との関連において追及してみる必要があるよう に思われる5),6)。影は鈠造材にはあらわれず，凝固組織 をむつあのについてのみあらわれるといわれているから である．溶接金属あるいは鋳造材の粒界には凝固の際低 融点の不純物が集まりやすく，またときには空孔ないし ボイドの発生するてとも知ら扎ている．乙ういったあの が粒界にあれば透過 X線写真では影となってあらわれる ことが考えられるわけである.

現在までに提出された影の発生機構としてはこれら 3 つのあのが代表的なあのであるようにみうけられる。し かしながらここでこれら 3 つの機構を比較してみた場合 そのいずれの間にも共通性がなく，またいずれの説もま だ現象をじゅうぶん説明するにいたっていないように思 われる、影の原因はまだ末解決のまま残されている，て の研究は影の原因を追及する目的で行なったものであ り，との報告ではまず影の形態ならびにその特長につい て述べる。

\section{II. 実験ならびに考察}

\section{A. 影の形態}

オーステナイト系ステンレス鋼溶接部ならびに鍀物の 透過 X線写真にあらわれる影の代表的なものを第 1 図に 示す、aはサブマーヂドアーク溶接部にあらわれた影で あり, 両側の母材部から溶接中央部に向かって発達した 影が中央部で突合わさった形となっている. 図でみられ 



Fig. 1 Typical appearances of the mottling. Columnar appearance is remarkable. (a), (b) and (c) show mottlings appearing on radiographs of austenitic stainless steel weldments. (a) submerged arc weld. base metal $304 \mathrm{~L}, 12.7 \mathrm{~mm}$ in thickness, wir $316 \mathrm{~L}, 4.8 \mathrm{~mm}$ in diameter. welding current $700 \mathrm{amps}$, welding voltage 34 volts, traveler speed $36 \mathrm{~cm} / \mathrm{min}$. (b) submerged arc weld. base metal $316 \mathrm{~L}$, $12 \mathrm{~mm}$ in thickness, wire $316 \mathrm{~L}, 4 \mathrm{~mm}$ in diameter. $500 \mathrm{amps}$, 35 volts, $30 \mathrm{~cm} / \mathrm{min}$. (c) TIG weld. base metal $304 \mathrm{~L}, 6 \mathrm{~mm}$ in thickness. wire $316 \mathrm{~L}, 4 \mathrm{~mm}$ in diameter. $280 \mathrm{amps}, 13$ volts, $9 \mathrm{~cm} / \mathrm{min}$. (d) a mottling appearing on radiograph of the weld joint of a boiler made of austenitic stainless steel plates. (e) a mottling appearing on radiograph of an 18:8 type stainless steel casting.

るように影はマクロ組織をかたちどってあらわれるとい う特長がある. 影のいま 1 つの特長は黒と白の模様がし ばしば対になってあらわれることである.この図であ柱 状晶をかたちどってあらわれた黒い影のすぐそばに黒い 影とよく似た形の白い模様がところどころに認められ る. この現象は試片がうすい場合たとえば後に示す第 3 図特に第 3 図 $\mathrm{c}$ の写真ではより明瞭に認められる.bは 別のサブマーヂドアーク溶接部にあらわれたまた異った 形の影を示す. この場合は溶接中央部に斑点状の影があ らわれている. c は TIG 溶接部にあらわれた影であ る. この場合は中央部にみられる線状の影が特長的であ る. $\mathrm{d}$ は溶接構造物の透過 $\mathrm{X}$ 線検査で発見された影であ る. 2 本の溶接線がまじわった付近の溶接部中央に明瞭 な線状の影がみられる. e はステンレス鋳物にあらわれ た影を示したあのである. 鋳物についてあ溶接金属の場 合と同様に影はマクロ組織をかたちどってあらわれるて とならびに黒と白の影が対になってあらわれるという現 象がみられる.

こてでどういった溶接条件の場合影がよく発生するの かということについては，まだじゆうぶんあきらかにさ れていない. 影はほとんどすべての溶接方法にわたって 発生しており, また溶接材料についてもオーステナイト 系ステンレス鋼に限らず, 高純度アルミニウム, 炭素 鋼, マグネシウムといったものについても認められてい る.

\section{B. 影亡 $\mathbf{x}$ 線の回折}

影の特長の 1 つである黒之白の影が対になってあらわ れるというととから, ただちに考えられるととは, X線
が何らかの理由によって回折されて影となるのではない かというととである. 黒い影は回折したX線によるもの であり, 白い影はそこにくるはずのX線が回折されてよ そに行ったため, X線が到達しなかったところであると 考えるととができる.

第 1 図 $\mathrm{c}$ に示した溶接部から第 2 図に示すように試片 $(21 \times 18 \times 3.8 \mathrm{~mm})$ を切り出し, 乙の試片を用いて X線 がどのように回折されて影となるのかしらべてみた. て

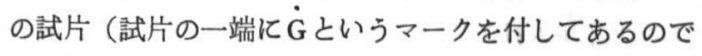
この報告では $\mathrm{G}$ 試片と呼ぶことにする）では第 1 図 $\mathrm{c} て ゙$ みられるように影が溶接中央部で線状にあらわれている ものであり, この線状の影に注目していくことによって 実験中に影を見失うことがないと考えたためである.な おこの試片では溶接部の裏面から表面に達する巾約 0.8 $\mathrm{mm}$ の柱状晶が第 2 図に示すように発達しており, 線 状の影はての柱状晶部から発生している. いっぽう母材 部から溶接中央部に向って発達した影は類似した形のも のが多数並んでおり, かつその一つ一つがてまかいため

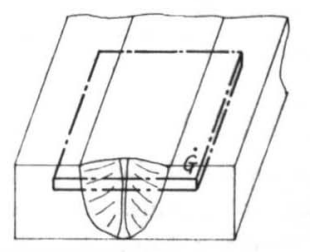

Fig. 2 Preparation of a specimen. A specimen, $3.8 \mathrm{~mm}$ in thickness, was machined of an austenitic stainless steel weldment shown in Fig. 1, (c). 



Fig. 3 X-ray diffraction and a resulting linear mottling.

(a) method of taking radiograph. (b) resulting radiograph, $d=0 \mathrm{~mm}$.

(c) $\mathrm{d}=4 \mathrm{~mm} \quad$ (d) $\mathrm{d}=10 \mathrm{~mm}$. (e) $\mathrm{d}=20 \mathrm{~mm}$. (f) $\mathrm{d}=30 \mathrm{~mm}$. target:

tungsten, voltage: 30.000 , thickness of the specimen $(\mathrm{t}): 0.5 \mathrm{~mm}$.

実験途中で相互に混同しあるいは見失うおそれがある.

X線が回折して影が生じたのであるかどうかをしらべ る目的で第 3 図aに示すように試片とフイルムの間隔を 順次あけて透過 X 線写真を撮影してみた. ての場合の試 料厚さは $0.5 \mathrm{~mm}$ であり, $\mathrm{X}$ 線源之試料間の位置関係 は一定に保ってある. 以下の実験で用いたX線源は特に ことわりのないかぎりウエルテス60 (嶋津製作所製) で ありフイルムは工業用 $\mathrm{X}$ 線フイルム RR 型である. また X線源と試片の距離は約 $250 \mathrm{~mm}$ であった.

得れた写真を $\mathrm{b} \sim \mathrm{f}$ 亿示す. 線状の影は試片とフイル 么間の距離が大きくなるにつれて中央部からはなれてい くことがわかる. いっぽう試片の中央部には残された白 い線状の影が認められ，乙の白い影と動く線状の黒い影
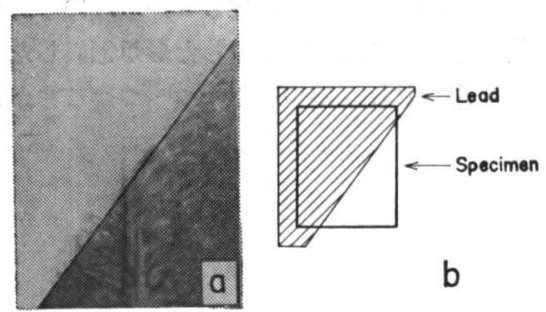

Fig. 4 An example of the mottling that reveals columnar crystals. In order to isolate the mottling from the direct image, a portion of the specimen was covered with a strip of lead and radiographed as shown in (b). tungsten, $\mathrm{V}=27.000, \mathrm{~d}=5 \mathrm{~mm}$, $\mathrm{t}=0.5 \mathrm{~mm}$.
は対になっているあのと考えられる．ての写真から影は X線が陚片によって曲げられて発生するあのであるてと がわかる.なおとの実験では溶接中央部にあらわれた線 状の影についてX線回折の様子をみたのであるが，母材 部から溶接中央部に向って発達した影についても第 4 図 で示すように同様の回折現象がみられる. 影を明瞭に示 す目的で， b図に示すように試片の1 部を鉛板で覆って 撮影した.

\section{X線照射角之影の関係}

溶接部の透過 X線写真撮影飞おいて, X線照射角を変 えてゆくと影のうちの 1 部のあのが消滅してゆくいっぽ うまた別に新しい影が発生するととが知られている. と のことから影はX線照射角の影響をうけるあのであるて とがわかる.しかしながらその精細についてはまだ明ら かでない.との研究では前述した $\mathrm{G}$ 試片を用い第 5 図a に示すようにX線照射角を変えて透過 X 線写真を撮影 し，照射 X線角と影の関係をしらべてみた。 まず武片を 表にむけ， $\alpha(\alpha$ は水平面上で試片を回転した場合の回 転角）を $0^{\circ}$ に保ったまま, 照射角 $\theta$ を $+15^{\circ} \sim-15^{\circ}$ の 範囲にわたって変えて撮影したのち, ついで試片を $\mathrm{b}$ 図 に示すように裹むけて同様の撮影を行なった. 表裹の各 場合いずれあ $\dot{G} マ$ クが図中に示したように右側にある ように設置した. 用いた試片は最初板厚 $3.8 \mathrm{~mm}$ であ ったが, 順次研磨してうすくしていき, 各板厚において それぞれ撮影を行なった. 試片の厚さ $0.5 \mathrm{~mm}$ の場合 試片の裏側から X線を照射して得られた写真を $\mathrm{c} \sim 1$ 亿 示す. 困でみうけられるように照射角 $\theta$ が $+15^{\circ} \sim+10^{\circ}$ 


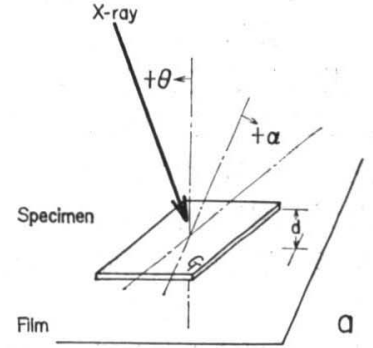

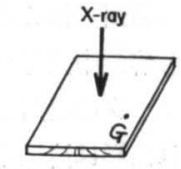

Rodiographed from the surfoce of the weld

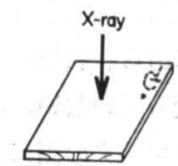

Rodiogrophed from



Fig. 5 Effect of the incident beam angle on the mottling. With the change of incident beam angle, the linear mottling, on one occasion, appears at the left side in the radiograph and it appears, on another occasion, at the right side. (a) representation of incident beam angle in the test. (b) the specimen radiographed from opposite directions. The specimen, $0.5 \mathrm{~mm}$ in thickness, was radiographed from the back side of the weld and some pictures obtained are shown in (c)-(1). tungsten, $\mathrm{V}=30.000, \mathrm{~d}=10 \mathrm{~mm}$, $\alpha=0^{\circ}$.
(c) $\theta=+15^{\circ}$

(d) $\theta=+12^{\circ}$

(e) $\theta=+10^{\circ}$

(f) $\theta=+7^{\circ}$

(g) $\theta=+6^{\circ}$

(h)

$\theta=+4^{\circ}$

(i) $\theta=+3^{\circ}$

(ji) $\theta=0^{\circ}$

(k) $\theta=-10^{\circ}$

(l) $\theta=-14^{\circ}$
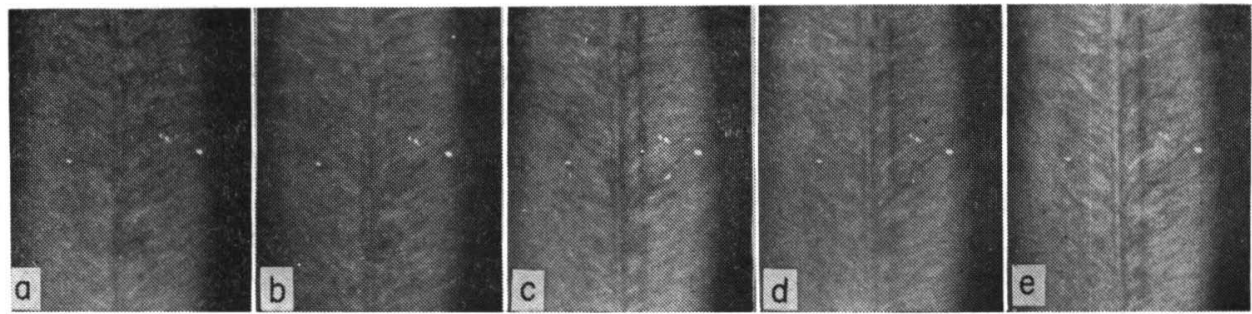

Fig. 6 Effect of a minute change in incident beam angle on the mottling. The specimen, $1.2 \mathrm{~mm}$ in thickness, was radiographed from the surface of the weld. The linear mottling appeared on a radiograph taken with an incident beam angle of ' $\theta=+8^{\circ} 30^{\prime}$, but it does not in the case of $\theta=+8^{\circ} 24^{\prime}$. tungsten, $\mathrm{V}=60.000, \mathrm{~d}=20 \mathrm{~mm}, \alpha=0^{\circ}$.
(a) $\theta=8^{\circ} 12^{\prime}$
(b) $\theta=8^{\circ} 24^{\prime}$
(c) $\theta=8^{\circ} 30^{\prime}$
(d) $\theta=8^{\circ} 36^{\prime}$
(e) $\theta=8^{\circ} 42^{\prime}$. 
の範囲では影は溶接中央部を界にして $\dot{\mathrm{G}}$ マーク（写真の 右下隅にみえる）と反対側に，かつ溶接中央部からほ之 んど等しい位置にあらわれた. 照射角が $+7^{\circ},+6{ }^{\circ}$ で は影はいったん消滅したのち $+4^{\circ} \sim 0{ }^{\circ}$ の範囲ではこん ごは $\dot{\mathrm{G}}$ マークの側にあらわれた. ここでも溶接中央部か ら影までの距離は変っていない, なお $\dot{\mathrm{G}}$ マークの反対側 にあらわれた影と $\dot{\mathrm{G}}$ マークの側にあらわれた影は溶接中 央部を界にしてほぼ対称的な位置にある.さらに角度を 変えるとー $10^{\circ}$ で影は再び $\dot{\mathrm{G}}$ マークと反対側にあらわ
れ，ついで消滅する. 第 6 図は照射角を微細に変化して 得られた写真を示す. この場合の板厚は $1.2 \mathrm{~mm}$ であ り X線は試片の表面から照射した. 照射角 $\theta$ がー $8^{\circ} 24^{\prime}$ まで線状の影は認められないが, $\theta$ がー $8{ }^{\circ} 30^{\prime}$ になると 影が突然あらわれる. わずかの角度变化によって影があ らわれたりあるいは消滅することがわかる.なお実験中 に時として影が溶接部の両側にあるいはどちらか片側に 2 本の線となってあらわれることがあった. 影が片側に 2 本の線となってあらわれた例を第 7 図 a に示す. この
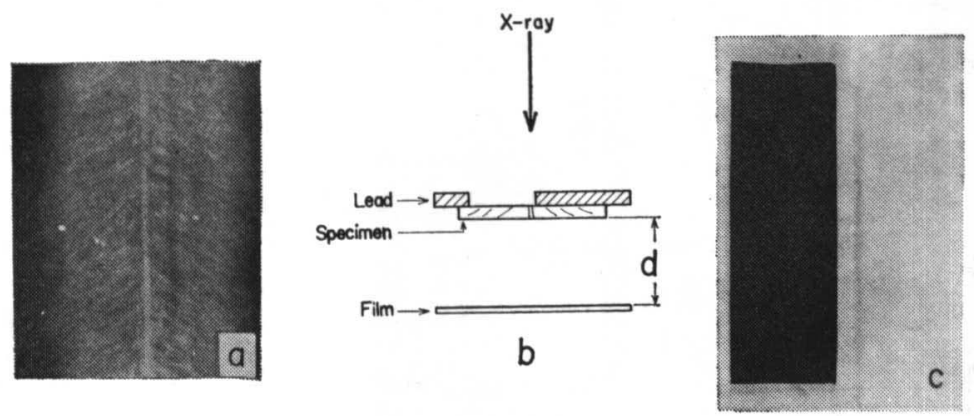

Fig. 7 An example of the mottling that reveals two linear mottlings. (a) ordinary radiograph. In order to isolate the two linear mottlings from the direct image, a half of the specimen was covered with a strip of lead and radiographed as shown in (b) and resulting radiograph is shown in (c). tungsten, $\mathrm{V}=60.000, \mathrm{~d}=20 \mathrm{~mm}, \quad \theta=0^{\circ}, \quad \alpha=0^{\circ}, \mathrm{t}=2.1 \mathrm{~mm}$

Table 1 Summary of the relation between the incident beam angle and the mottling.

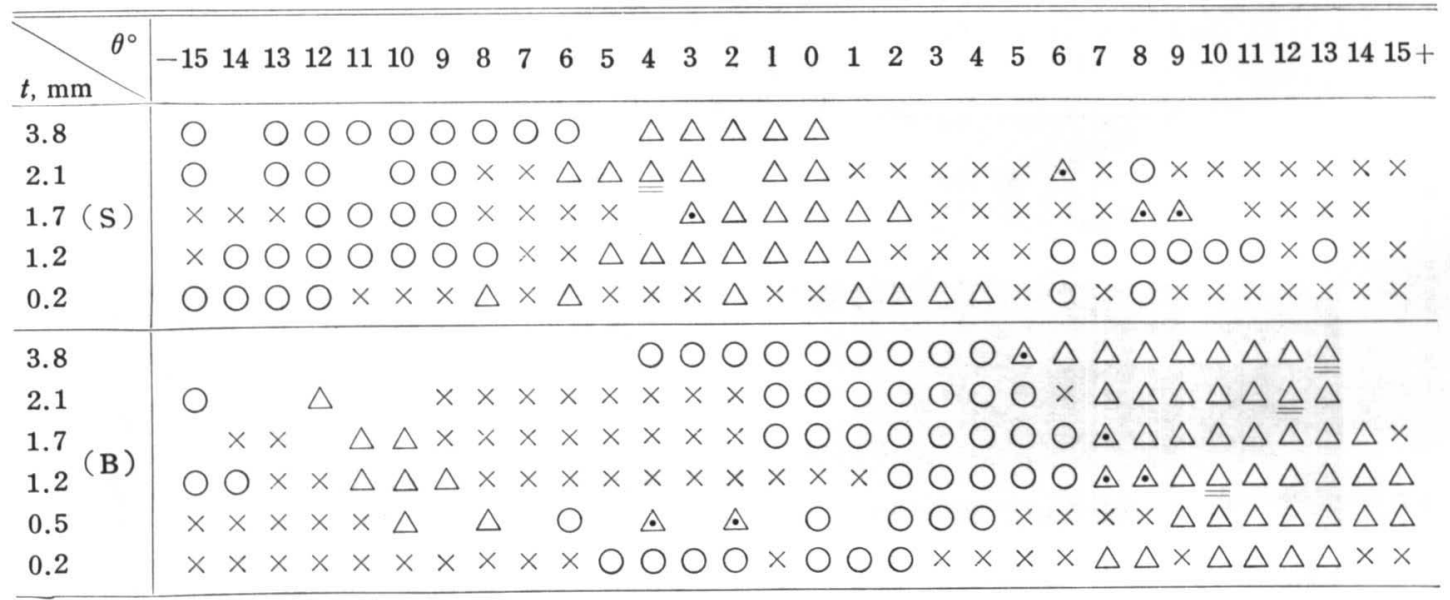

$\triangle$ : the linear mottling appearing at the left side on the radiograph.

$\bigcirc$ : the linear mottling appearing at the right side on the radiograph.

$\triangle$ : two linear mottlings appearing at one side on the radiograph.

$\Delta$ : the linear mottling appeareing at both sides on the radiograph.

$\mathrm{t}$ : thickness of the specimen.

$\theta$ : incident beam angle. $\left(\alpha=0^{\circ}\right)$

(S ) : radiographed from the surface of the weld.

(B) : radiographed from the back of the weld. 
場合影をより明瞭に示す目的で武片の 1 部を b図に示す ように鉊で覆って撮影した写真をc 亿示す.

第 1 表は $\mathrm{G}$ 試片を $3.8 \mathrm{~mm}$ から $0.2 \mathrm{~mm}$ まで順次薄 くしていった場合，各段階の板厚におけるX線照射角之 影の関係を一括して示したものである.表中で○印は影


ぞれあらわれたととを示し，×印は影があらわれなかっ



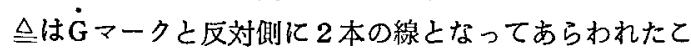
とを示す．な打 S は試料表面加ら，B襄面加らそれぞ れX線を照射した場合である、いずれの板厚の場合も類 似した関係がみられる。

第 $8 ， 9$ 図は第 1 表に示した影とX線入射角の関係を 板厚 $1.2 \mathrm{~mm}$ の場合について説明的に示したものであ る.第 8 因は試片の表面からX線を照射した場合であ る. $\mathrm{A}\left(+13^{\circ}\right)$ 加ら入射した $\mathrm{X}$ 線は結晶による回折と

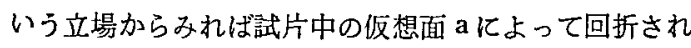
て $\mathrm{A}^{\prime}$ の方向に進む. ここで回折角は約 $4^{\circ}$ である.ま た B からのX線は仮想面 b で回折され B $^{\prime}$ の方向に進 む. この場合の回折角も約 $4^{\circ}$ である. A B の間の角

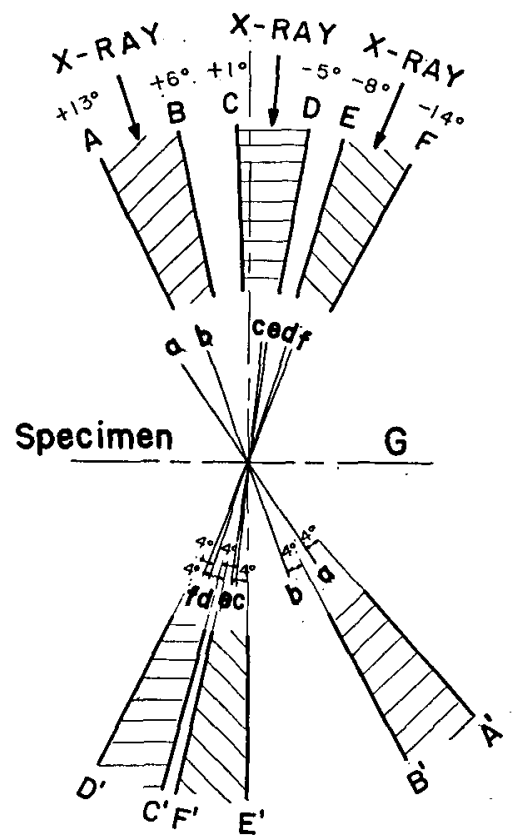

Fig. 8 " A diagram showing the diffraction of incident X-ray beams by the specimen. Radiographed from the sufgace of the specimen. If the incident beam angle is between $A$ and $B$, for example, the diffracted beam lies between $B^{\prime}$ and $A^{\prime}$. The diffraction angle remained nearly constant.
度で入射した X線は，a面〜 b面の間にある仮想面群の うち，回折角が $4^{\circ}$ となる面によって回折されて， $\mathrm{A}^{\prime} \sim$ B'の間の方向にそれぞれ進行古る. 入射 $\mathrm{X}$ 楾が $\mathrm{B} \sim \mathrm{C}$ の間にあれば影はあらわれず，C〜Dで再びあらわれる ようになる，乙の場合入射 $\mathrm{X}$ 線は $\mathrm{c}$ 面とd面の間の傾き をもった仮想面群によってそれぞれ回折されて $\mathrm{C}^{\prime} \sim \mathrm{D}^{\prime}$ の間の方向に進む. ての場合の回折角むやはり約 4 ○で ある. 入射角が D Eの間のあのは影があらわれず $\mathrm{E} \sim$ Fで三度影があらわれる．との場合は $\mathrm{e}$ 面〜 f 面の間に ある仮想面によ゙って回折角約 $4^{\circ}$ で回折されてそれぞれ $\mathrm{E}^{\prime} \sim \mathrm{F}^{\prime}$ の間の方向に進む. ここで c 面と $\mathrm{e}$ 面, $\mathrm{d}$ 面と f 面は図面ではほとんど一致している. そこで仮に $2 つ$ の面群を同じあのであるとみるならば，ての1群の面に よって入射角がC〜Dの間のX線は図上で左側に，また $\mathrm{E} \sim \mathrm{F}$ 間の入射 $\mathrm{X}$ 線は右侧にそれぞれ回折されたととに なる・

第 9 図は試片の裹加らX線を照射した場合の説明図で ある・との場合む試片の表から $\mathrm{X}$ 線を照射したのと同様 の現象がみられる。

さて影はその回折角が約 $4^{\circ}$ で試片の一端から他端に

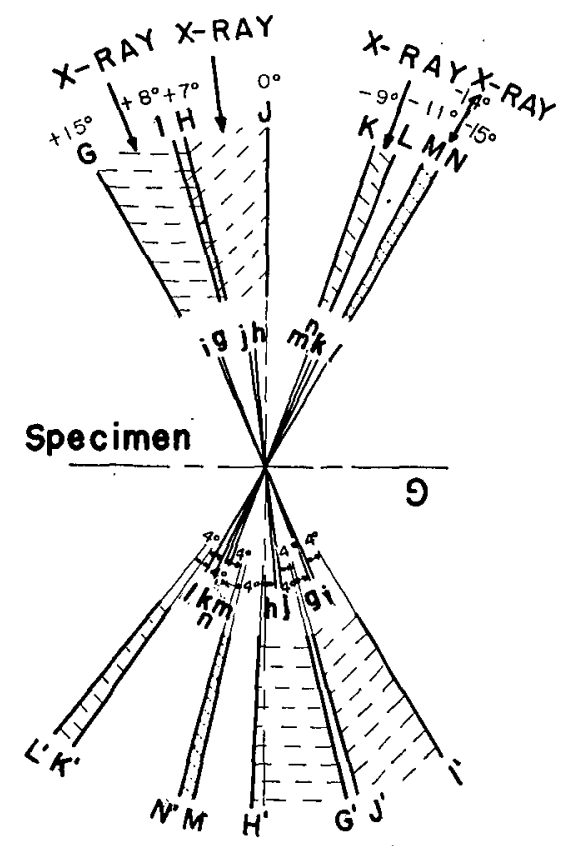

Fig. 9 A diagram showing the diffraction of incident X-ray beams by the specimen. Radiographed from the back of the specimen. If the incident beam angle is between $G$ and $H$, the diffracted beam lies between H' and G'. The diffraction angle again remained nearly constant. 
まで達する線としてまたある角度範囲にわたり連続して あらわれるという特徵がある，影がいわゆる結晶面によ るX線回折によって起とるという立場でてういった条件 を満足するためには，試片中央部の巾約 $0.8 \mathrm{~mm}$ の柱 状晶部に特定の結晶面がある角度範囲にわたって連続し て存在し，かつこれらが試片の端から端まで切れ目なく 続いているととが必要である. しかす第 8，9図からあ わかるようにこういった条件をみたす面群が少くとす 2 つ必要なわけであり，G試片の場合そういった面群の 1 つは $+17^{\circ} \sim+10^{\circ}$ の間の傾きをすった面群と $-3^{\circ} \sim-$ $10^{\circ}$ の間の傾きをもった面群であるということになる。 てういったことから考えて，単なる結晶面によるX線の 回折という立場だけで影の現象をを説明するのは困難で あるように思われる。

ての実験中に影がときとして両側にあるいは片側に 2 本の線になってあらわれたととについてはすでに述べた 通りである。こういった現象は照射角との微妙な関係に

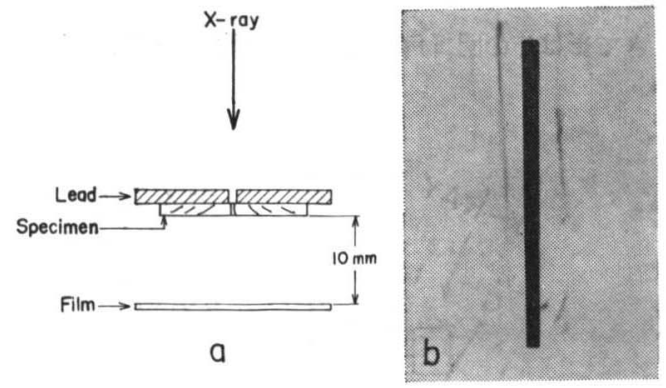

Fig. 10 An appearance of the mottling. In order to isolate the mottling from the direct image, the specimen, except the central area of the weld, was covered with a strip of lead and radiographed under a condition of $\theta=+4^{\circ}$ and $\alpha=20^{\circ}$, as shown in (a). Resulting radiograph (b) shows four linear mottlings that run parallel with each other. tungsten, $\mathrm{V}=40.000, \mathrm{~d}=10 \mathrm{~mm}, \mathrm{t}=0.5 \mathrm{~mm}$.
おいてあらわれたあのと考えられる. この現象を明ら加 にするため照射角 $\theta$ のみでなく $\alpha$ をむ变化して撮影を 行なってみた．影をなるべく明瞭に示すため，影の発生 源である前述した溶接中央部の柱状晶のみを露出し，他 の部分は鉊でおおってX線を照射した．撮影状況を第10 図 a に得られた結果を bにそれぞれ示す. 照射角 $\theta, \alpha$ を適当にえらぶことによって影は左右ほぼ対称に数本の 線となってあらわれる. 両側の影はそれぞれ 1 次, 2 次 の影とみられ，乙の現象は細陌による光の回折模様とよ く似たあらわれ方をしているように思われる.

\section{D. 試片厚さと影の関係}

第11図は $\mathrm{G}$ 試片について, 板厚の異なる場合の透過 $\mathrm{X}$ 線写真を示したあのである.いずれの板厚の場合あ影は 明瞭にあらわれているのであるが，板厚が小さくなるに つれて影あ瀻細化する傾向にある.

\section{E. X線管電圧の影におよばす影響}

透過X線写真像がたとえば気泡といったようなものに よって生じている場合は，できるだけ管電圧を下げ， $\mathrm{X}$ 線の波長を長くして撮影することによって，より明瞭な 像が得られるはずである. 物質の質量吸収係数之用いる X線の波長の関係からとのととがいえる. 第12図は影に およぼす X 線管電圧の影響を $\mathrm{G}$ 試片の板厚 $0.5 \mathrm{~mm}$ の 場合について示したあのである. 図でみられるようにX



Fig. 11 Specimen thickness and the mottling. Specimen thickness makes little difference in the mottling. (a) thickness, $t=3.0 \mathrm{~mm}$. (b) $\mathrm{t}=2.1 \mathrm{~mm}$. (c) $\mathrm{t}=1.2 \mathrm{~mm}$. tungsten, $\mathrm{V}=60.000, \mathrm{~d}=20 \mathrm{~mm}, \quad \theta=0^{\circ}, \quad \alpha=0^{\circ}$.
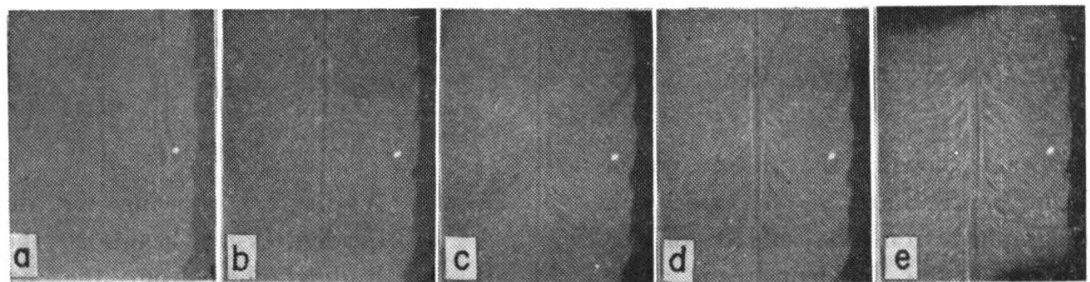

Fig. 12 Effect of the votlage applied to an X-ray tube on the mottling. The mottling was more pronounced on a radiograph taken with a low voltage than in one taken with high voltage. (a) $\mathrm{V}=60,000$. (b) $\mathrm{V}=40,000$. (c) $\mathrm{V}=35,000$. (d) $\mathrm{V}=$ 30,000. (e) $\mathrm{V}=27.000$. tungsten, $\mathrm{d}=0 \mathrm{~mm}, \quad \theta=-2^{\circ}, \quad \alpha=0^{\circ}, \mathrm{t}=0.5 \mathrm{~mm}$. 
線管電圧を下げ, X線の波長を長くし, したがって露出 時間を長くして撮影すると影は著しく明膫になる. この 結果は影の原因についての粒界との関連における空孔な いしはボイド説を支持するあのとみうけられる.

\section{F. 影の微細構造}

$\mathrm{X}$ 線照射角を適当化選定し, かつX線管電圧をなるべ く低くして長期間露出し，もって透過 X 線 写真を撮影 し, 瀻細な影を得た. 用いた試片は $0.5 \mathrm{~mm}$ の G 試片 であり, 第 7 図bに示したように試片の半分を鉛でおお って撮影した. X 線源としてはラヂオフレックス 100 DS (理学電機製) を用い, その焦点サイズは $1 \times 1 \mathrm{~mm}$ であり, X線源と試片間の距離は約 $300 \mathrm{~mm}$ とした. い ままで 1 本の線とみられていた影は実は細い数本の線が からみあってできているあのであるてとがわかる. こて で影の両端がそれぞれ反対方向に曲っているのは興味深 い現象である.

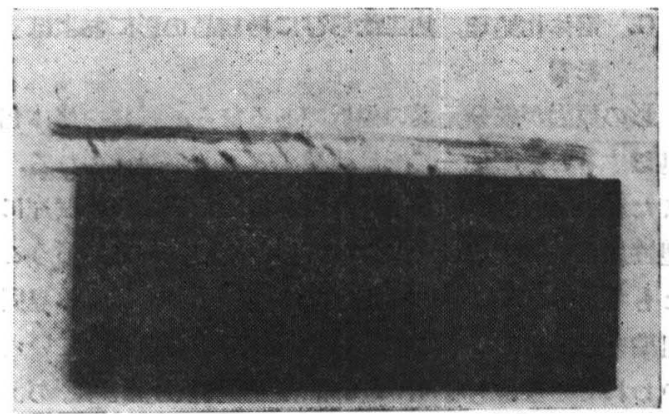

Fig. 13 Micro-structure of the mottling. A half of the specimen was covered with a strip of lead and radiographed as shown in Fig. 7 (b). In order to reveal the micro-structure of the mottling, radiograph was taken with very low voltage and much longer exposure time. The resulting ragiograph shows that the mottling consists of several fine lines which are intertwined mutually. tungsten, $\mathrm{V}=22,500 . \theta=-13^{\circ}$, $\alpha=+45^{\circ} \mathrm{t}=0.5 \mathrm{~mm}, \mathrm{~d}=5 \mathrm{~mm}$.
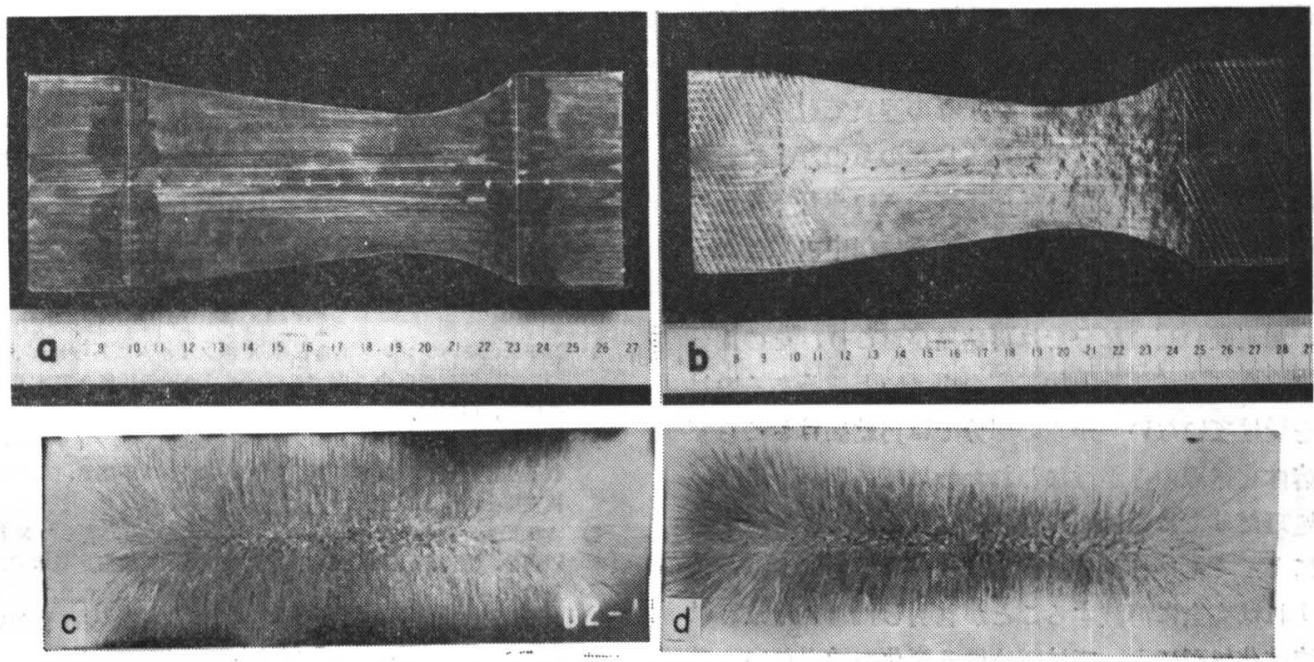

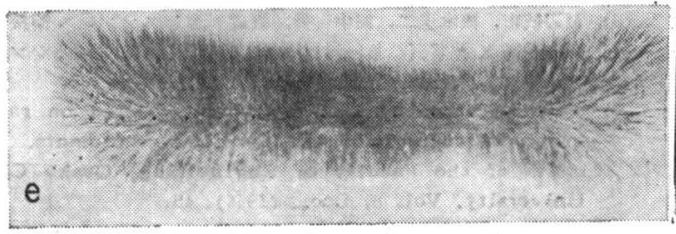

04.05 .05 .09 .09 .09 .8 I2.9 I5.0 24.02t.0 I5.4 9.8 5.00

Elongation (\%)

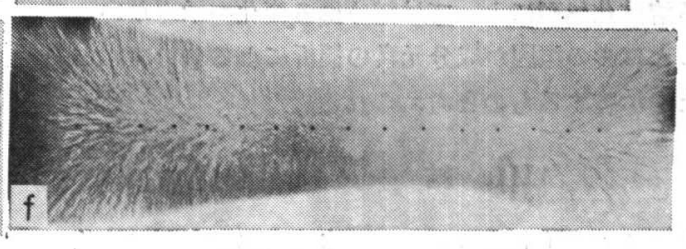

O 4.05 .05 .09 .09 .09 .812 .915 .024 .021 .015 .49 .85 .00

Elongation (\%)

Fig. 14 Effect of cold working, solution treatment and recrystallization on the mottling. The mottling tends to disappear when the specimen is cold worked. Solution treatment does not affect the mottling. The mottling disappears, however, if the specimen is recrystallized. A specimen shown in (a) was stretched as shown in (b). The stretched specimen, then, was heated at $1100^{\circ} \mathrm{C}$ for lhour and quenched in water. (a) specimen, $10 \mathrm{~mm}$ in thickness, ready for stretch working. (b) specimen after stretching. (c) radiograph of a cast 18:8 stainless steel plate used for the test. (d) readiograph of the specimen before stretching. (e) radiograph of the specimen after stretching. (f) radiograph of the specimen after heat treatment. 


\section{G. 溶体化処理，加エならびに再結晶の影におよぼす 影辠}

影の原因が成分元素の偏析であるなら，試片を溶体化 処理するととによって影は消滅することが期待される. また影の原因がボイドといったものであるなら，試片に 塑性加工を加えることによって影が変化するであるうこ とあ考えられる、いっぽうすでに述べたように影は疑固 組織をむつあのにあらわれ，鍛造材ではあらわれないと いわれている.むしそうであれば疑固組織をすち影のあ らわれる試片ですてれを再結晶させると影は消滅するは ずである.とういった各種姏理とその影に抽よばす影響 を明らかにする目的で 18-8ステンレス鋼鋳物の板を用 い第14図 aに示す非対称の引張試片を製作し，これをb 図に示すように引張加工したのち， $1100^{\circ} \mathrm{C} \times 1 \mathrm{hr}$ の溶 体化処理を行なった. この処理の各段階で得られた透過 X線写真を第14図 c， d , e, f 亿示す. この場合のX線源 はラヂオフレッグス $100 \mathrm{DS}$ であり, 試片とX線源間の 距離は約 $430 \mathrm{~mm}$ であった. 写真 $\mathrm{c}$ は用いた18-8 ステ ンレス板の透過X楾写真であり， d はこれを引張試片に 加工したのちのものである.いずれの写真でも影は明瞭 にあらわれている．e は引張加工したのちの写真である が断面積が小さくしたがって加工度の高い部分では影は ぼやける傾向にある. 試片各部の伸びは図中に示した. f は加工後溶体化処理を行なった陚片についての写真で ある. 加工度の高い部分では再結晶がおてり，その部分 で影は完全に消隇した．加工度の小さいところあるいは 加工を受けていないつかみの部分では再結晶はおてらず ただ溶体化処理のみが行なわれたわけであるが，てうい った処理だけでは影は認め得る変化を示さない，以上の 実験によって影は加工によってぼやける傾向にあり，再 結晶すれば完全に消隇するてとが判明した.いっぽう単 なる溶体化処理によっては認め得る変化を示さない．と のととは影の原因が成分元素の偏析によるものではない ととを示唆するものと考えられる.

\section{III. 結}

語

オーステナイト系ステンレス溶接金属ならびに鋳物の 透過X線写真化あらわれる影飞ついて次のととがわかっ た.

1. 影は疑固組織をかたちどってあらわれるてとなら びにしばしば黒と白の影が対になってあらわれる という特徴がある.

2. 影はX楾が回折して生ずるあのである.

3.しかしながら単なる結晶面によるX線の回折とい う立場だけから影の現象を説明するのは困難であ
るように思われる。

4. 影の発生とX線照射角の関係を明らかにした。 ま た照射角を適当に定めることによって，ちょうど 細陌による光の回折模様に類似した影が得られ た.

5. 試料厚さによって影が大きく変化するてとはな い.しかしながら試料がうすくなるにつれて影す 繊細になる傾向にある。

6. X楾管電圧を低くし，X線波長を長くして撮影す ると影は著しく明瞭になる．乙の現象は影の原因 としての粒界との関連に斿ける空孔ないしはボイ ド説を支持するあのであるように思われる.

7. 影は多くの細い線からできているようである.

8. 塑性加工を加えることによって影はぼやける傾向 にある.

9.溶体化処理によって影は認めうる変化を示さな い.とのととから成分元䒺の偏析が影の原因であ るとは考えられない。

10. 影が明暸にあらわれる試片であてれを再結晶させ ると影は完全に消滅する．影は凝固組織をあつも のについてのみあらわれ，鍛造材についてはあら われないるのであるととがわかった.

\section{文献}

1) 富田真己：ステンレス溶接部の X 稼フイルムにあらわれる陰影に

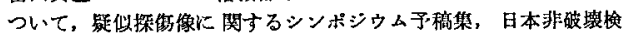
查協会，(1963).

2）河村敏一，武本隆彦：ステンレス溶接部の X 線フイルムにあらわ

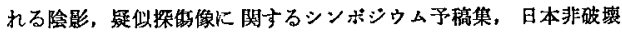
梌查協会, (1963).

3）入江正㟥，藤井政夫，山下庄吾：ステンレス鋼溶接部の $\mathrm{X}$ 線虽状

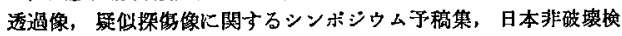
查協会，(1963).

4）藤并政夫，佐治 実, 土并文士：ステンンス溶按部の X 線異状探 俈像, 溶接学会誌, 第33巻 (1964).

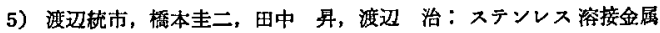
部の透過 X 線写真化尚らわれる影，键似探侮像に関寸るシンボシ ウム予稿集, 日本非破墂㭘查協会。(1963).

6) Toichi Watanabe: The mottling appeared on radiograph of austenitic stainless steel weldments. Me moirs of the Faculty of Engineering, Osaka City University. Vol. 8, Dec., (1966), 45.

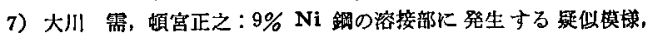
日本非破塔検查協会資料，(1969).

8) W.H. Glaisher, W. Betteridge, R. Eborall: The Mottling of Aluminum alloy radiographs. J. Inst. Metals 70, 81 (1944), 81.

9) R. Mayoud, P. Guiraldeng : Influence de la structure macrographique Sur les images radiographiques dáciers inoxydables moulés. Memoires scientifiques Rev. Metallurg. LXIII, No. 9, (1966), 757.

10）一也昼文，高正 植, 片岡邦郎，水沢宮蜼：フルミ合金の透過畏

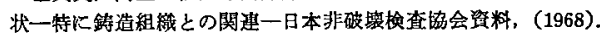

11) A. Taylor: X-ray metallography. John Wiley sons. (1961), 54 . 